ARTICLES

Copyright (C) 2012 SBPjor / Brazilian

Association

of Journalism

Researchers

\section{FALSE, INACCURATE AND INCOMPLETE NEWS:}

\section{challenges facing journalists in voluntary} rectification. The Spanish experience

\author{
ANTONIO LÓPEZ HIDALGO \\ Universidad de Sevilla \\ ÁNGELES FERNÁNDEZ BARRERO \\ Universidad de Sevilla
}

\begin{abstract}
Journalists must verify information provided by their sources. However, factors such as job precariousness, urgency and the credibility they give to mainly institutional sources mean that journalists do not verify information. Most codes of conduct recommend the duty to correct information as soon as an unintentionally committed error is discovered, but journalists dislike recognising their own errors and even more so correcting them publicly. These circumstances affect adversely the quality of discourse and the credibility of mass-media. Ombudsmen partially bridge this gap. As a result, false, mistaken, wrong or biased pieces of news are published and journalists, against the rules of truth and honesty, rarely rectify on their own initiative. This article analyses the coverage of Iraq's weapons of mass destruction, in which the game of mimicry saw the same mistake repeated in different media and in different countries, although prestigious newspapers published an unusual public apology.
\end{abstract}

Keywords: Credibility. Voluntary rectification. Accurate information. Journalism quality. Ethic.

\title{
NOTÍCIAS FALSAS, INCORRETAS E INCOMPLETAS: Os desafios dos jornalistas em busca da retificação voluntária. A experiência espanhola
}

RESUMO - Os jornalistas devem verificar as informações fornecidas por suas fontes. Contudo, alguns fatores como a precariedade no trabalho, o imediatismo e a credibilidade que eles dão, sobretudo às fontes institucionais, leva os jornalistas a não verificarem a informação. Vários códigos de conduta recomendam a obrigação de corrigir a informação assim que se descobre que um erro não-intencional foi cometido, mas os jornalistas não gostam de reconhecer seus próprios erros, nem de corrigi-los publicamente. Essas circunstâncias afetam a qualidade do discurso e também a credibilidade dos meios de comunicação. Ombudsmen preenchem parcialmente essa lacuna. Como resultado, fragmentos de notícias falsas, equivocadas, erradas ou enviesadas são publicadas por jornalistas, contrariando as regras de verdade e honestidade, sendo raramente retificadas por iniciativa própria. $\mathrm{O}$ artigo analisa a cobertura das armas de destruição em massa do Iraque, na qual, como em um jogo de imitação, o mesmo erro foi sendo repetido em diferentes meios e em diferentes países, apesar de alguns jornais prestigiosos publicarem um pouco usual pedido de desculpas.

Palavras-chave: Credibilidade. Retificação voluntária. Informação precisa. Qualidade do jornalismo. Ética. 


\section{NOTICIAS FALSAS, INCORRECTAS E INCOMPLETAS: Ios retos que deben afrontar los periodistas en el proceso de rectificación voluntaria. La experiencia española.}

RESUMEN - Los periodistas deben contrastar la información suministrada por sus fuentes informativas. Sin embargo, algunos factores como la precariedad laboral, la premura con la que se elaboran las informaciones y la credibilidad que se le da a las fuentes, principalmente a las institucionales, propician que el periodista no verifique ni contraste sus informaciones. La mayoría de los códigos de conducta recomiendan la obligación de corregir la información tan pronto como se ha detectado el error involuntario, pero a los periodistas no les gusta reconocer sus propios errores, y mucho menos corregirlos de forma pública. Estas circunstancias afectan a la calidad del discurso periodístico y la credibilidad de los periodistas y medios de comunicación. Los defensores de la audiencia suplen, en parte, este vacío. Como consecuencia, se generan, involuntariamente, informaciones erróneas o falsas, parciales o inventadas, y el periodista pocas veces rectifica el error por iniciativa propia. Este artículo analiza la cobertura periodística del tema de las armas de destrucción masiva en Irak, en el que, siguiendo un proceso de imitación, el mismo error fue reproducido por diferentes medios en diferentes países, aunque algunos periódicos prestigiosos publicaron una inusual disculpa pública.

Palabras clave: Credibilidad. Rectificación voluntaria. Información precisa. Periodismo de calidad. Ética.

\section{INTRODUCTION}

In the mid-19th century, there was a shortage of news, particularly true and verifiable news. Technological advances had a marked influence on driving informative journalism. Now, in the 21 st century, the flow of news is remarkable, and at times even excessive. Media bureaux have favoured source-based journalism, which is clearly seen on a daily basis in what has come to be called 'journalism of assertion' or 'he said, she said' journalism. The broadcast media have also smoothed the path. It is a programmed type of journalism with the opinions of sources acting as the backbone of the news genres. Also, this type of journalism is devoid of substantiation. Journalists rely blindly on institutional and confidential sources alike.

However, at times, journalists publish inaccurate or false information because they have been manipulated or not given the correct documentation by the source. The affected reader has the right of rectification and their ombudsman intercedes between the reporter and the public to clarify inaccurate information. But only rarely, exceptionally rarely, does a journalist rectify on his own initiative. It is also true that rectifying may prove counterproductive because it may cause people who did not read the rectified text subsequently to take an interest in it. Thus, rectification paradoxically contributes to propagating the very fact that was intended to be rebutted. 
This article seeks to promote a theoretical reflection on these issues, drawing on information provided by different sources. The literature review will allow the establishment of a framework covering this subject and the analysis of multiple tendencies and perspectives. Also, the coverage of Iraq's weapons of mass destruction will be analyzed, and this case reveals a uniform behaviour on the part of the press, persisting with the error regarding the existence of those weapons.

\section{CONSIDERATIONS ABOUT TRUTH IN THE NEWS}

Bill Kovach and Tom Rosenstiel, authors of The Elements of Journalism, devised a principle shared by all: journalism's first obligation is to the truth. They also add, however: 'On this there is absolute unanimity and also utter confusion: everyone agrees journalists must tell the truth, yet people are befuddled about what 'the truth' means' (KOVACH and ROSENSTIEL, 2007, p. 36).

Certainly, journalists have never been clear when referring to the truth. Kovach and Rosenstiel (2007, p. 41) blame journalists for their passivity, of being mere recorders of events, rather than selectors and editors. They add that originally, in principle, it was not the journalist who had to be objective, it was their method. Over the years, some journalists have suggested substitutes in the search for the truth. The most common of these could be impartiality and fairness. But neither suffices. Impartiality is an abstract and subjective concept. Equanimity is also subjective. In recent years, the press has opted for opinion-based interpretation too. In the 21 st century, verification and synthesis must become the new guardian angels of journalists. As Kovach and Rosenstiel state, the need for truth is greater in this century, not smaller, given that the potential for lie-mongering is much larger.

In their work Blur: How to Know What's True in the Age of Information, Kovach and Rosenstiel (2010) focus on the importance of verification, fact-checking and evidence in the media as a method of reporting, 'the way of sceptical knowing'. They outline a method that citizens can use to discern the truth for themselves, in a context where the media face a deluge of portable, personalized, and participatory news. Thus, everyone must become an editor, assuming the responsibility for testing evidence and checking sources presented in news stories, deciding what it is important to know, and whether the material is reliable. This method requires six steps: identifying the nature of the content being consumed (journalism of verification, journalism of assertion, journalism 
of affirmation, interest-group journalism, or journalism of aggregation); examining whether a news account is complete; steps three and four deal with sources: the identity of those sources and the nature of the evidence that is adduced; the fifth step is to consider whether there is an alternative explanation; and finally, exploring whether the news is providing what is needed.

Niceto Blázquez (1994, p. 208-212) emphasises the concept of truth and states that this term applies when recipients learn of the truth through the media. In other words, it is the truth or reflection of reality that the informer ascertains and communicates to people as faithfully as possible using the mass media. However, they distinguish between informing objectively (referring to things as they stand in their own context, without manipulation or distortion) and being truthful (it may not necessarily coincide with exactly how things are in their pure objective state). From this, Blázquez infers that the truth always refers to reality to the extent that it is known, rendering truth an analogical concept, which can be told from many different realities.

The journalist is not always present when the event they aim to report on occurs. As a result, they are conditioned by or subjected to the version that sources offer of the event. It is also true that access to certain information will always be influenced by the sources. The journalist consequently publishes the reality they know or are given by sources. Blázquez (1994) justifies the journalist's role because they safeguard their moral honesty by being truthful, by telling the facts as they understand them after adequate investigation and verification. Nonetheless, what is said may not necessarily be the absolute truth. Veracity in many cases is whatever is morally possible, and therefore is the safeguard of journalists' honesty.

Thus far, attention has been devoted to the process of verification before the publication of a news story. The journalist may err without intending to, either because they have been misinformed or because sources have misled them or provided them with inaccurate information. The problem lies in the fact that the journalist generally does not verify the information supplied by sources. They give sources unreserved credit. Yet the source's commitment is not always underpinned by the same honesty, as is the case with journalists.

It may be that journalists, under pressure to produce news, do not have enough time to substantiate and verify facts, data, numbers, comments or dates. But in other instances too, when information comes to light, the journalist detects pitfalls and checks if the news is 
inaccurate, incomplete or false. They publish it in good faith, believing that their news reality is reliable. However, even if they know they are wrong, they do not rectify mistakes. Journalists must aspire to tell the truth and, when they are wrong, rectification is the most appropriate way to correct the error because if they fail to carry this out, they mislead. As Blázquez (1994) points out, the informer who is not truthful, misleads. From then on, they lose the right to inform. Making a mistake may be ethically correct. Deliberately misleading never is.

\section{DISINFORMATION FROM INFORMATION SOURCES}

The best source of information is the event or fact itself, advances Alba Sánchez in an El Nacional article called The Trap, on 23 November, 2004. If the journalist is present when the event occurs, there is no problem, as they are both the witness and source to everything that happens. But this is not always the case, and, as Burgueño (1997) explains, journalists do not have the gift of ubiquity and this is precisely where the dilemma lies. As a result, the journalist must rely on their sources, yet not all sources are reliable. Casals Carro (2005, p. 109) rightly states that the relationship of the journalist with information sources is the main problem in journalism. Certainly, the journalist draws on information sources to produce their own text. In certain cases, it could be said that these may even condition the work routines of the informer and their take on the facts, especially when they are concerned about losing access to information sources used on a daily basis.

In any case, none of the information sources can prevent professionals from spreading rumours, indoctrination, non-events, disinformation, pseudo-events, trial balloons, scoops, or invented, inaccurate, incomplete, biased or false news. Nowadays, the journalist tends not to substantiate or verify the content of the sources, especially if the latter are public or institutional. They put all their trust in them and reporters have become more relaxed. However, as Kovach and Rosenstiel (2010, p. 78) explain: 'credentials alone are insufficient'. The employment situation, of course, is changing work routines. Job insecurity has led the journalist to adopt a more passive and cosy, but less committed, attitude. This can also be noticed in the topics tackled, the poor quality of the sources drawn on to produce the stories, in the quality of the writing and the handling of a scant number of journalistic genres.

More significantly, there is the limited number of rectifications in the different media that the journalist makes public on his own initiative. 
The journalist is not blameworthy when they are wrong. In the words of Niceto Blázquez (2005, p. 208-212), the journalist protects their moral integrity merely by being truthful and recounting facts as they know them, after adequate investigation and verification. However, what is said is not necessarily the absolute, objective truth. The absolute objective truth is the ideal. Veracity is what is morally possible in many cases, and therefore, what really protects their integrity.

Nevertheless, journalists get facts wrong, make unintended mistakes, and mention only the part of the reality they know about. Meanwhile, their integrity remains intact. After the information is published, the journalist detects the mistake, the lie, the fiction and deceit. But they do not normally rectify facts, and least of all opinions. As Kovach and Rosenstiel (2010, p. 119) explain, no one demands much more than a correction when an analysis is wrong. Mea culpa tends to be offered for mistakes of a more clear-cut nature, even if they are more innocent (misspellings, misidentifications or typos in addresses).

Blázquez (1994) is categorical about this, stating that in order morally to compensate for involuntary flaws in objectivity, codes of conduct recommend the duty to correct information as soon as the unintentionally committed error is discovered. The informer who informs truthfully may be wrong, but cannot be morally accused of deceiving the public if there was no culpable negligence and they are prepared to make amends.

Nevertheless, if the journalist does not rectify inaccurate news that is already published, can they be accused of deceiving the public or of negligence? The truth in news may also be published in a series of instalments, but it must be done. Rectifying is for the wise and also for journalists.

Most probably, as Kovach and Rosenstiel (2007) point out, the root of the problem is that the journalist is unaware that objectivity is the main tool for making the method effective. Journalists must be subjective, honest and wary. They should not consider information provided by sources as definitive and good, and should ask the source for as much corroboration, evidence and proof as deemed necessary to be able to substantiate and verify the facts being added to the news mix.

\section{DISINFORMATION AND WEAPONS OF MASS DESTRUCTION IN IRAQ COVERAGE}

It is also worth asking, for instance, whether US journalists were fulfilling their obligation when they reported on the statements made 
by President Bush about the existence of weapons of mass destruction (WMD) in Iraq, even though it would subsequently be shown that these weapons did not exist. Of course, Bush made these statements and he is consequently responsible for them. However, this logically raises the question of whether the journalist's function is to attend a press conference and repeat everything he is told there, without requesting further documentation or verifying what they have been told. Not a single journalist did. Journalism of assertion is a dead-end alley which professionals would be well-advised to avoid. Today, one can only imagine how many journalists and newspaper companies were absolutely convinced of the distant possibility that WMD did not exist. Time has passed, but the question still needs to be answered.

Spain was part of the coalition forces that invaded Iraq, arguing that it had weapons of mass destruction that represented a threat to international security. To reinforce this argument, on 5 February, 2003, the then US Secretary of State for Security, Colin Powell, attempted to present the media with irrefutable evidence which demonstrated the danger Iraq posed. Powell backed up his appearance with satellite images and graphics. According to a report published in Spain's El País on 7 February 2003, 'in the US, the country's leading newspapers gave huge credibility to Colin Powell's arguments, and considered indisputable the absolute lack of willingness by Saddam Hussein's regime to cooperate with the UN', while 'in Europe more importance was given to the unconvincing nature of the evidence'. Three days later, Bush announced that Iraq may have trained Al Qaeda in the use of biological and chemical weapons.

Nevertheless, the argument as to whether WMD existed in Iraq had already been brewing for months. In Europe, for example, various media published an unusual manifesto in the press on 30 January that same year. It was signed by eight European heads of state (Spain, Portugal, Italy, UK, Hungary, Poland, Denmark and the Czech Republic) with the title 'United We Stand'. The manifesto said: 'Our goal is to safeguard world peace and security by ensuring that this regime gives up its weapons of mass destruction'. The text stemmed from an initiative by The Wall Street Journal and was a response to the campaign orchestrated to justify the war. In the US, the Bush Administration had been pushing this message for months; it had appeared in prestigious dailies such as The New York Times, courtesy of specialised journalists such as Judith Miller.

For Massing, the handling of the news on WMD is significant 
because it also highlights a uniform, mimetic behaviour by the press: 'The contrast between the press's feistiness since the end of the war and its meekness before it highlights one of the most entrenched and disturbing features of American journalism: its pack mentality. Editors and reporters don't like to diverge too sharply from what everyone else is writing. When a president is popular and a consensus prevails, journalists shrink from challenging him' (MASSING, 2004). In this game of mimicry, media have maintained the same mistake in almost every area, in an example of 'clerkism', the term adopted by the reporter Homer Bigat to define 'the practice of uncritically accepting the official version of things' (KOVACH and ROSENSTIEL, 2010, p. 27).

Kovach (apud EKAIZER, 2005) maintains that the major newspapers, which played a critical role at other times, opted, for political and financial reasons, to adopt a principled stand: not to challenge George Bush's government on the subject of Iraq; or in other words, to almost always give them the benefit of the doubt during war preparations, against a background in which the $7 / 11$ attacks also help explain the role played by the press in supporting Bush during the preparations for the invasion of Iraq. 'The attacks were used by the Bush Administration to create sensitivity in the media (...). We now know it was a carefully calculated operation' (EKAIZER, 2005, p. 32). This patriotic atmosphere swept up newspapers as prestigious as The New York Times and Washington Post 'For the neoconservatives, 7/11 was a golden opportunity to defend the stance on the Iraq war', according to John J. Mearsheimer and Stephen M. Walt (2006), from Harvard University, who also stress the influence of the Israeli lobby and the neoconservatives on US foreign policy and the North American press.

With the excuse that Iraq had WMD, the international coalition forces, led by the US, invaded Iraq on 20 March 2003 under the slogan "Operation Iraqi Freedom". In Spain, the government faithfully toed the Bush Administration's line and, the then prime minister, Aznar, emphatically maintained in a number of TV interviews that were widely reported in the press that the arms existed: 'You and everyone watching can be sure that I'm telling the truth,' he insisted, for example, in an interview broadcast on 13 February on Antena 3 TV. 'The Iraqi regime has weapons of mass destruction; it has ties with terrorist groups and has demonstrated throughout its history that it is a threat to us all'.

Although the media, which were ideologically aligned with the government opposition, openly declared themselves to be against intervention in Iraq ('The war against Iraq is not just undesirable, 
it is avoidable,' said El País in the editorial 'Iraq, an undesirable war', published on 26 January 2003; and 'for the first time, a government in democratic Spain is backing a war that is not supported or authorised by any international organisation, be it global, like the UN, or regional, like NATO and the EU in the case of Kosovo,' in the editorial 'Heading towards an Illegal War', of 18 March 2003), they did not use sufficient resources to investigate the existence of WMD, even though it was already known from January 2003 that UN inspectors had found none after five weeks of searching, and that the declarations of El-Baradei, then Director General of the International Atomic Energy Agency (IAEA) had had some impact in Europe, when he questioned the validity of the evidence presented by the Bush government on the existence of WMD in Iraq. The report, which the Bush Administration ignored, did not have the impact in the US or Europe it needed to mobilise public opinion, or to make the media defenders of the public interest instead of broadcasters of the political agenda. In similar terms, Susan D. Moeller (2004), from the University of Maryland's Center for International and Security Studies, concludes that the media tended to lump together all types of WMD, gave too much credence to the administration's arguments and failed to air dissenting views.

Media pressure on the coalition forces when faced with allegations of manipulating evidence against Iraq over the existence of WMD, gained momentum in the more liberal media a few months after the invasion, when the first echoes from the international press were felt and when the opposition parties began to pressure the government for explanations. As early as 17 May 2003, Ernesto Ekaizer, a journalist at El País, suggested in a piece entitled 'The Mystery of WMD', that 'following a considerable number of false rumours, there is not a single sign of weapons that were brandished as the threat that needed to be eliminated through war'. Ekaizer insists there was a propaganda battle on WMD that began on Tuesday 5 February, with Powell's press conference. Four months later, in September, El País announced that the ' 1,400 US investigators were unable to find evidence of weapons of mass destruction' (25 September 2003), despite the Spanish government's insistence on the truthfulness of the story.

In fact, in his speech to the US Congress, Prime Minister Aznar maintained that 'the threat of weapons of mass destruction is real' (EL PAís, 25 February 2004). In February 2004, El Mundo compiled a list of the ten occasions when Aznar emphatically pointed to this threat.

In October 2004, the first news emerged that the US had been unable to find WMD from a report by experts commissioned to track 
down the Iraqi arsenal. The team was headed by Charles Duelfer, of the $\mathrm{CIA}$, who stressed that Saddam wanted, but was unable, to produce WMD and that Iraq's nuclear potential had diminished, not increased, since the Gulf War of 1991. But it was not until January 2005 that the US finally abandoned its search for WMD after disbanding the units involved in the mission. It was only in 2007 that former Prime Minister Aznar first admitted there were no WMD in Iraq during a conference in Madrid. 'My problem is I wasn't smart enough to know about it earlier. No-one knew,' he said.

On the role played by the media, Bob Woodward (EKAIZER, 2007), the journalist who investigated the Watergate scandal with his partner Carl Bernstein, said that it was extremely difficult for a journalist in 2003 to find proof of the incorrectness or falseness of the assertion regarding WMD in Iraq. That would have required an investigation into these arms on Iraqi territory before the war -something that Saddam would not have allowed- although he acknowledged he was wrong not to have dug deeper. However, the media also erred in being too trusting of official sources, in abusing 'the journalism of declaration' and in their lack of a more interpretative journalism, which could have traced precedents, drawn connections between different pieces of information, analysed the US's possible interests, and anticipated any possible consequences given that the world's complex reality was strangled in the facts.

Kovach and Rosenstiel (2010, p. 44) consider that the case of misinformation concerning WMD shows the extreme effects of journalism of assertion, in which the news culture, technology, deadlines, rumours, innuendos, hypotheses, speed, passivity and culture of immediacy, lead to common mistakes. Assertions should be backed up with evidence. Journalism of verification tends to prioritize the evidence corroborating data (the two source rule), verifying information in a multiplicity of sources and seeking proof empirically. These authors recommend the method called 'portable ignorance' (KOVACH and ROSENSTIEL, 2010, p. 103), developed by Homer Bigart during the Vietnam War. Bigart asked numerous simple questions and followed the thread of the answers until he knew more about the situation than anyone else.

Ramonet wonders why the main US media companies did not verify or question the statements made by the Bush Administration, explaining that a CIA field officer, Robert Baer, revealed how the system of news manipulation worked: 'The Iraqi National Congress (INC) took information from false deserters and passed it on to the Pentagon. The INC then gave that same information to journalists, saying: 


\begin{abstract}
If you don't believe it, call the Pentagon'. That was how they managed to create a type of closed-circuit system with these news stories. The New York Times was thus able to say it had two information sources on WMD in Iraq. The same thing happened at The Washington Post. Journalists made no attempt to dig deeper. Meanwhile, editorial heads asked them to back the government. As patriots (RAMONET, 2005).
\end{abstract}

Some media also dwelled on these issues and apologised to their readers. The management of The New York Times, for instance, issued a mea culpa. After reviewing the published material in the prelude to the war and the early stages of the occupation, in an article published under the headline 'The Times and Iraq' (26 May 2004), they found that occasional 'information that was controversial then, and seems questionable now, was insufficiently qualified or allowed to stand unchallenged'. The New York Times states that: 'looking back, we wish we had been more aggressive in re-examining the claims as new evidence emerged -or failed to emerge'. The editors, however, insisted that the errors were institutional as opposed to individual: 'Some critics of our coverage during that time have focused blame on individual reporters. Our examination, however, indicates that the problem was more complicated. Editors at several levels who should have been challenging reporters and pressing for more scepticism were perhaps too intent on rushing scoops into the paper'.

Four days later, the paper's ombudsman, Daniel Okrent, published a highly critical analysis entitled 'Weapons of Mass Destruction? Or Mass Distraction?' (30 May 2004) in which he pointed out that the newspaper's coverage of Iraq in the months prior to the invasion and the following weeks, was 'partial' and 'ingenuous'. Okrent analyses the practices that led The Times down this unfortunate path and highlights factors including: the hunger for scoops; the front-page syndrome; hitand-run journalism (the more surprising the story, the more often it must be revisited) and the coddling and anonymous sources. Also it is argued that: 'The Times itself was used to further their cunning campaign (referring to the tactics of those who promoted the WMD stories) and stresses the paper's institutional responsibility; but pinning this on Miller alone is both inaccurate and unfair'.

Despite this, many media experts criticised the role of journalists at The New York Times. During the war, Judith Miller was invested in a special military unit whose mission was to find the weapons; while Michael R. Gordon, a defence correspondent, was responsible for coverage of the invasion. Michael Massing (2004) accuses her of putting too much 
trust in Ahmed Chalabi as a source and in other Iraqi exiles who were obvious conspirators in offering the White House and the Pentagon the arguments needed to invade Iraq. But previously, Slate, The Nation, Editor \& Publisher, American Journalism Review, and the Columbia Journalism Review had all run articles accusing her of being too eager to accept official claims before the war, and too enthusiastic to report the discovery of banned weapons afterwards. Meanwhile, Bill Kovach, assured readers in an interview published in El País (EKAIZER, 2005) that if the news from Judith Miller had been subject to an investigation similar to that into the work of Jayson Blair, it would have come to the same conclusion. Jayson Blair left the newspaper in 2003 after an internal investigation showed he was guilty of frequent deception in major stories: a systematic news fraud that consisted of copying, plagiarising, inventing, exaggerating and falsifying many of his articles, some of which were on the front page.

In addition to The New York Times, The Washington Post joined the ranks of the US media which apologised. In this case, it was a personal initiative by reporter Howard Kurtz (2004), who usually covers media news and who published the column Media Notes several times a week on the paper's website. The article slammed the Post for failing to scrutinize vigorously the Bush administration's claims about Iraq's supposed WMD and for relegating articles that did challenge the White House view to inside pages where they would receive less attention and cause little fuss.

This public mea culpa shows an interesting and unusual example of integrity and responsibility. In Spain, the game of mimicry has not been applied in this case, so clear apologies have not been published, although the El País ombudsman said on 5 April 2009, in reference to this and other issues that 'we journalists must never forget that our first obligation is to seek the truth and this is based on facts, not on versions that blindly follow propaganda strategies'.

Professor Labio maintains that the Iraq conflict is proof that manipulation can assume many guises. Despite the lie about WMD, information was hidden (the German newspaper Die Tageszeitung revealed that the US government removed 8,000 of the 11,800 pages in the original report about WMD submitted by the Iraqi government to the UN), efforts were made to censor news gathering (prior to the invasion of Baghdad, the Pentagon asked journalists to leave the Iraqi capital), to control journalists sent to the conflict (it ensured it included well-established informers in the military units), omissions were made (such as those relating to human rights violations and the murders 
of journalists). In Iraq, thousands of civilians and over 200 journalists died, according to French NGO Reporters without Borders, including the Telecinco cameraman José Couso and El Mundo's correspondent Julio Anguita Parrado. As in other wars, the first casualty was the truth.

\section{TRUTHFUL INFORMATION AND DUE DILIGENCE BY THE JOURNALIST}

In an interesting article published in the $A B C$ newspaper, 'Truthful Information and the Journalist's Due Diligence', on January 14 2002, Professor of Information Law Luis Escobar de la Serna (2002, p. 64) points out that, where truthfulness is concerned, the Spanish Constitutional Court does not demand absolutely incontrovertible facts but that the informer be diligent in investigating them. Because of this, he warns that inaccurate information is inevitable in an open discussion. This means that if 'truth' were imposed as a condition for recognising the law, the only guarantee providing a legal safeguard would be silence. The author acknowledges that narrating the event or news story involves their subjective participation in two ways: firstly in the way they interpret the sources used to prepare the story; and secondly, in deciding how to convey it so that the news is broadly the result of a reconstruction or interpretation of real facts.

In terms of diligence by the journalist and their medium in investigating the truthfulness of the information being communicated, De la Serna notes that truthful information under article 20.1d) of the Spanish Constitution, means information that is checked in accordance with the rules of news professionalism, and excludes inventions, rumours and innuendos. Similarly, the author notes that for the Spanish Constitutional Court, due diligence by the informer is also demonstrated when they rectify inaccurate information. In these exceptional cases, it adds, when 'the informer's diligent and responsible attitude is being investigated (Ruling 40/1992 by the Constitutional Court), it is important not to lose sight of the subsequent timely correction of the published information'. Indeed, the addition of a rectification, if produced spontaneously on the initiative of the author of the information or the newspaper that issued the news, or at the instruction of the affected party, is clearly 'revealing of the attitude of the newspaper or journalist in search of the truthfulness of what has been reported'.

On this subject, Camilo Osorio Isaza, Colombia's Attorney General, has written that all professionals, and particularly communicators 'carry moral baggage, which acquires sense and merit based on the 
awareness that each of them has of what their personal dignity is worth' (Osorio Isaza, 2003). However, fortunately, it is only on rare occasions that the error becomes the prominent element in the events; the journalist, feeling cornered and harried, must make amends, as best and as soon as they can, before the public shows their eternal distrust. Osorio Isaza believes that by publicly acknowledging errors and adopting clarity and transparency, credibility can be earned. The reader obviously appreciates this level of sincerity. Nor can it be forgotten that rectification is a mechanism that provides the opportunity to offer the complete truth of the facts, even if it is piecemeal and made public on two occasions. However, ultimately, the outcome of rectification becomes a credential of authenticity and responsibility.

\section{CAN RECTIFICATION PROVE COUNTERPRODUCTIVE?}

At times, rectification does not fully make amends from the point of view of a party deeming themselves negatively affected. Sometimes, rectification may also be counterproductive. That is the opinion expressed by Casasús, who considers that: 'Some readers, who did not read the rectified text, are then prompted to take an interest in it. In this case, rectification paradoxically contributes to the propagation of what was intended to be rebutted' (CASASÚS, 2001 a).

$\mathrm{He}$ insists that this collateral effect should be considered when a journalist is ready to rectify, but adds it should not prevent 'the tonic of rectification being administered if the person affected believes it is in their best interests' (Casasús, 2001b). Nevertheless, Casasús dispels any doubt further on:

Rectification of what the news media disseminate is a right that protects everyone. But more than anything else, it is a moral obligation, an ethical principal, a deontological commitment that all reporters must respect, with or without laws that regulate them. Rectification is a fundamental duty (CASASÚS, 2001b).

Rectification may at times be counterproductive but, in any case, the consequences of adopting the opposite position, in other words a refusal to rectify, may be even more detrimental. Often, as Desantes points out, published news is not true not because it is absolutely false, but because it has been published prematurely (DESANTES, 1976, p. 115). This generally tends to happen with expected deaths. Instances are more common in the digital media, where pressure for immediacy and content updating is greater, yet urgency has also spelled trouble for the 
printed and broadcast media. This was evidenced, for example, when TVE and CNN+ announced the death of singer Rocío Jurado two days before she actually passed away, or when CNN+ reported the death of Pope John Paul II while he was still dying.

There have been many instances of 'untimely' deaths, even on the front page. For example, in its online edition of 29 December 2006, El País published 'Fidel Castro dies' on its front page. The elpais.com website kept the headline on its home page for some minutes, long enough for it to be detected and reported. El País rectified by deleting the headline but did not give any explanation regarding the error. For a quality newspaper like this, that explanation might have caused less damage to its credibility.

Cronkite (1996, p. 63) laments that the press is losing credibility mostly because of its lack of accuracy. But what he demands above all else is the ability to correct and rectify mistakes and that the correction be given the same prominence as the error. Aguilar has written along similar lines:

Some days ago, a newspaper wrote that a famous former footballer was being investigated for alleged drug-money laundering. A few days later, the footballer in question refuted the information point by point. The news was published in four columns on an oddnumber page; the refutation was hidden like a letter to the editor. While this situation persists, we will not be credible (AGUILAR, 2004, p. 8).

\section{TOWARDS A CULTURE OF RECTIFICATION}

The points that have been discussed are not recent developments, as demonstrated in the International Principles ${ }^{1}$, the most universal document of rules in the area of professional ethics in journalism, approved by the UNESCO General Assembly on 21 November 1983. Article 5 sets out the following: 'The nature of the profession demands that the journalist promote access by the public to information, and participation of the public in the media, including the right of correction or rectification, and the right of reply'.

Another code of conduct with far-reaching territorial reach is the declaration on professional conduct adopted by the International Federation of Journalists ${ }^{2}$, which is also categorical: 'The journalist shall do the utmost to rectify any published information which is found to be harmfully inaccurate'.

In the case of humanitarian catastrophes and tragedies, Hugo Aznar refers to journalists' ethics, recognizing that particularly in such situations, journalists need to be aware of ethical considerations, writing: 
The ethical demands for committed and quality journalism become even more fundamental in a situation of crisis. From tightening obligations -such as checking the news or its attribution, immediate rectification, etc. -to applying those obligations required by a special situation. Service logic must prevail more than ever in the work of the media in these situations (AZNAR, 2005, p. 88).

Among other documents, it is worth making a final reference to the Journalists' Style Guide Manual, which was used at the Forum for Immigration (2000) and the Association of Journalists of Vizcaya, to protect the culture, rights and image of immigrants in the news. This document states that: 'Rectifications of information referring directly or indirectly to foreign non-EU residents should be accepted as standard and beneficial practice for the press. Rectification must be spontaneous and prompt. We must move towards a culture of rectification'.

The style guides used by different newspapers devote a significant amount of space to the issue of rectifying. However, they devote neither the space that these issues deserve nor the required clarity. Many style guides make reference only to errata and minor aspects that raise questions as to the journalist's diligence in rectifying.

\section{PERSISTING WITH THE ERROR IS SOMETHING JOURNALISTS DO}

Among other functions, all ombudsmen should be vigilant that these norms are adhered to, remind people that they are in place and promote the practice of this professional obligation even if it is 'not always gracefully accepted as a matter of fact by those who should comply'. This is the opinion held by Casasús (2001b), who recognises that this is a generalised phenomenon. He recalls that during a meeting of ombudsmen in Paris, it became clear that 'there is the occasional journalist in any editorial office who still reacts churlishly and goes on the defensive when faced with the basic duty of rectifying'.

His predecessor in that position at La Vanguardia, Roger Jiménez, explained this attitude by professionals in an interview with Daniel Capella for the Capçarela press magazine, in April 1994: 'No-one likes to see their own name being cited for a mistake but we have to be aware that all of us make mistakes and have to overcome the excessive fear we have in acknowledging it in Spain'. De la Serna, erstwhile Ombudsman at El País, expresses himself in the same terms in statements published by the Diario de Navarra newspaper on 5 November 1993: "When I show up at the editorial office with a piece of paper, I see people watching me pass by and expressing relief when I move along. Nobody likes admitting 
to making a mistake and even less so if it is going to be published'.

In fact, journalists dislike recognising their own errors and like correcting them publicly even less. One need only skim through a newspaper to appreciate that rectifications made on the journalist's own initiative are highly unusual and almost never occur. To a certain degree, ombudsmen in the broadcasting sector have re-established this responsibility which news professionals have disregarded at their desks. However, their work often amounts to little more than nuances of style, offering explanations on published news, correcting unclear titles, and so on.

There is another complication: in Spain, few media have this type of ombudsman. Hence, not even the role played by ombudsmen can compensate for the shortage of rectifications needed in the Spanish media. This is even more the case when professionals do not seem particularly set on addressing this skewed situation. Possibly exaggerating in his explanation, the ombudsman at the sensationalist newspaper The Sun said ironically of his colleagues in the profession: 'To err is human, to persist with the error is something journalists do'. Javier Darío Restrepo, the readers' ombudsman at El Colombiano, also writes:

\begin{abstract}
The journalist insists on their error out of vanity, and thinks they will lose professional standing if they admit they were wrong; or they stubbornly refuse to revise the underlying arguments in their statement because they are obstinately convinced that they are right; or through fear of being disciplined by their superiors. Whatever the reason, persistence with the error is not typical of the journalist; it is the exception that proves the rule (RESTREPO, 2002).
\end{abstract}

Professor Hugo Aznar, from Valencia University, also looks at the position taken by the media and professionals, again with the aim of proposing a change of attitude:

\begin{abstract}
Since the media lives off the credibility afforded to them by the public, it has been standard policy to do whatever is possible to cover up their errors. However, the end result of that policy is counterproductive. The public ends up with a less than positive image of the media and the members of the profession, seeing them as one of the most arrogant and inept groups when it comes to acknowledging their faults. Attitudes need to change. Given that the work of the media is to scrutinise other institutions, it is not particularly clear - and the public realises this - why they exclude themselves from the healthy practice of criticism (AZNAR, 1999, p. 176).
\end{abstract}

Restrepo (2002) believes that the reader has ceased to believe in infallible newspapers, people or institutions that hide their errors and 
balk at admitting them. In its Code of Practice, the Press Complaints Commission, the independent self-regulatory body for the British press, stresses that any inaccurate, misleading or distorted information 'should be promptly corrected and with due prominence,' and also where appropriate, 'an apology published'. Restrepo understands that the newspaper offers intangible products: accuracy and credibility. He therefore adds that 'whenever an inaccurate news story reaches readers, the newspapers' obligation is to correct, clarify or rectify as clearly and effectively as a certain car manufacturer did when it replaced defective wheel rims. There is no reward in this act. It is an act of justice because the client must be supplied with the product they have been offered to buy. And the reader is a client who is purchasing accuracy and credibility'.

\section{CONCLUSIONS}

The implementation of the culture of rectification is sought, in theory, as the result of a long journey. But no forward steps will be made unless the profession acknowledges the need for such change. Journalists, working with the mass media as a whole, must be willing to reject journalism of assertion and passive journalism, to condemn press conferences where questions are not allowed; they should reject their role as simple mouthpieces for institutions and raise the banner of objectivity as a method, and ethical subjectivity and honesty as necessary tools for promoting the truth. For the reward to materialise, it needs to be nurtured by substantiating and verifying facts, and rectifying if news sources mislead when people are mistaken.

\section{$I_{\text {NOTES }}$}

1 The International Principles of Professional Ethics in Journalism were prepared as an international common ground and source of inspiration for national and regional codes of ethics, to be promoted autonomously by each professional organization through ways and means most adequate to its members.

2 The International Federation of Journalists adopted the IFJ Declaration of Principles on the Conduct of Journalists at the Second World Congress in Bordeaux in April 1954, which was amended at the 18th IFJ World Congress in Helsingör in June 1986. 


\section{IREFERNCES}

AGUILAR, J. La credibilidad de los periodistas (The Credibility of Journalists). Diario de Sevilla, Comment Section, 29 January 2004, p. 8.

AZNAR, H. Comunicación responsable (Responsible Communication). Barcelona. Ariel, 1999.

AZNAR, H. Ética de la comunicación y nuevos retos sociales. Códigos y recomendaciones para los medios (Ethics in Communication and New Social Challenges). Barcelona, Paidós, 2005.

AZNAR, et al. United We Stand. Wall Street Journal, 30 January 2003. Available at: http://www.opinionjournal.com/extra/?id=1 10002994. Accessed on: 26 May 2011.

BLÁZQUEZ, N. Ética y Medios de Comunicación (Ethics and Media). Madrid. Biblioteca de Autores Cristianos, 1994.

BURGUEÑO MUÑOZ, J.M. Fenomenología de la invención en el periodismo informativo (The Phenomenology of Invention in Informative Journalism), PhD thesis. Complutense University of Madrid, Spain, unpublished, 1997.

CASALS CARRO, M.J. Periodismo y sentido de la realidad. Teoría y análisis de la narrativa periodística (Journalism and A Sense of Reality.Theory and Analysis of Journalistic Narrative) Madrid. Fragua, 2005.

CONGRESS OF THE REPUBLIC OF BOGOTA. Speech by Attorney General of Colombia Dr Luis Camilo Osorio Isaza, at the Ethics in Journalism Forum. Congress of the Republic of Bogota, Colombia, on 12 June 2003. Available at: http://www.fiscalia.gov.co/pag/ divulga/Decla02/foroetica.htm. Accessed on:17 March 2006.

CASASÚS, J. M. Unos derechos ante la prensa. (Rights with the Press) Observatório da Imprensa, 1 19, 2001 a. Available at:http:// www.observatoriodaimprensa.com.br/artigos/voz020520012.htm. Accessed on:26 February 2003.

CASASÚS, J. M. Rectificar es de periodistas. (Rectifying is for Journalists) Observatório da Imprensa, 127, 2001b. Available at:http://www.observatoriodaimprensa.com.br/artigos/ voz270620015.htm. Accessed on:9 February 2004.

CRONKITE, W. A Reporter's Life. New York. Alfred Knopf Inc Publication, 1996. 
DESANTES GUANTER, J. M. La verdad en la información (The Truth in News). Valladolid. Diputación Provincial de Valladolid, 1976.

EKAIZER, E. Cometí un error al no investigar más sobre las armas de destrucción masiva ('I was wrong not to investigate WMD further'). El País, interview to Bob Woodward, Sunday supplement, 4 February 2007, pp. $11-12$.

EKAIZER, E. La prensa compró las 'mentiras nobles' de Bush (The press bought Bush's 'noble lies'). El País, interview to Bill Kovach, 6 February 2005, p. 32.

ESCOBAR DE LA SERNA, L. Información veraz y diligencia del periodista (Truthful News and The Journalist's Due Diligence). ABC, 14 January 2002, p. 64.

IMMIGRATION FORUM. Manual de Estilo Periodístico. 2000. Available at:http://www.periodistasvascos.com/imagenes/inm.pdf

KURTZ, H. The Post on WMD: An Inside Story. The Washington Post. 12 August 2004. Available at: http://www.washingtonpost.com/wpdyn/articles/A58127-2004Aug1 1.html. Accessed on:27 May 2012.

LABIO, A. Poder y Manipulación Informativa. Una aproximación desde el pensamiento crítico. Razón y palabra, February- March 2005, $\mathrm{n}^{\circ}$ 43. Available at: http://www.razonypalabra.org.mx/anteriores/n43/ alabio.html Accessed on:31 May 2012.

MASSING, M.: Now They Tell Us. The New York Review of Books. 26 February 2004. Available at: http://www.nybooks.com/articles/ archives/2004/feb/26/now-they-tell-us/. Accessed on:25 May 2012.

MEARSHEIMER, J. and WALT, S. El lobby israelí y la política exterior estadounidense (The Israeli Lobby and US Foreign Policy). Faculty Research Working Papers Series. Harvard University, John F. Kennedy School of Government. Buenos Aires, 2006. Available at: http://www. laeditorialvirtual.com.ar/pages/Mearsheimer_Walt/ElLobby.htm

MOELLER, S. D. Media Coverage of Weapons of Mass Destruction. Philip Merrill College of Journalism, University of Maryland, College Park. 9 March 2004. Available at: http://www.cissm.umd.edu/papers/ files/WMDtudy_full.pdf

KOVACH, B. and ROSENSTIEL, T. The Elements of Journalism. New York. Three Rivers, 2007.

KOVACH, B. and ROSENSTIEL, T. Blur: How to Know What's True in the Age of Information. New York. Bloomsbury Publishing USA, 2010.

RAMONET, I. Medios de comunicación en crisis. Le Monde 
Diplomatique, 10 January 2005. Available at:http://www.mondediplomatique.es/2005/01/ramonet.html. Accessed on:7 January 2008.

RESTREPO, D.: La caída de los dioses infalibles. (The Fall of the Infallible Gods) El Colombiano, 12 January 2002. Available at: http:// elcolombiano.terra.com.co/defensor/ediciones/enero12-02.html. Accessed on:9 February 2004.

OKRENT, D.: Weapons of Mass Destruction? Or Mass Distraction? The New York Times, 2306 May 2004. Available at: http://www.nytimes. com/2004/05/30/weekinreview/the-public-editor-weapons-of-massdestruction-or-mass-distraction.html?pagewanted=all\&src=pm. Accessed on:20 May 2012.

THE NEW YORK TIMES: The Times and Iraq. The New York Times, 26 May 2004. Available at: http://www.nytimes.com/2004/05/26/ international/middleeast/26FTE_NOTE.html?pagewanted=all. Accessed on:20 May 2012. 
FALSE, INACCURATE AND INCOMPLETE NEWS:

BRAZILIAN JOURNALISM RESEARCH-Volume 8-number z- əoIæ| 227 